\title{
The Relationship Between Coagulation Tests and Stage in Lung Cancer Patients
}

\section{Akciğer Kanseri Tanılı Hastalarda Koagülasyon Test Değerlerinin Tanı Anındaki Evreyle İlişsisi}

\author{
Sema Yılmaz Rakıcı ${ }^{1}$, Özlem Terzi ${ }^{2}$ \\ ${ }^{1}$ Recep Tayyip Erdoğan Universitesi Tıp Fakültesi, Radyasyon Onkolojisi Dalı \\ ${ }^{2}$ Ondokuz Mayıs Üniversitesi Tıp Fakültesi Halk Sağlığı Anabilim Dalı
}

GİRiş ve AMAÇ: Bu çalışmada akciğer kanserli hastalarda koagulasyon testlerindeki değişikliklerin sağkalım ve uzak organ metastazı üzerine etkisi araştırıldı.

YÖNTEM ve GEREÇLER: Çalışmamız, hastanemiz radyasyon onkolojisi kliniğine başvuran primer akciğer kanseri tanısı almış hastaların verileri retrospektif değerlendirilerek yapıldı. Yaş, cinsiyet, histopatolojik tanı, metastaz durumu ile koagulasyon test değerleri ve yaşam süresi arasında iliş̧i analiz edildi.

BULGULAR: Çalışmaya toplam 342 hasta dahil edildi. Hastaların \%18.4'ü küçük hücreli akciğer kanseri (KHAK) iken \%81.6 küçük hücreli dışı akciğer kanseri (KHAK) tanısına sahipti. KHDAK'li hastalarda en sık görülen histopatolojik alt tip Adenokarsinom (\%45.0) idi. Tüm hastalar için uzak organ metastaz oranlarına bakıldı̆̆ında hastaların \%44.4'ünde uzak organ metastazı yokken, \%55.6'sinda uzak organ metastazı vardı. KHAK'li hastaların \%65.1'i, KHDAK'lı hastaların ise \%53.4'ü uzak organ metastazı olan ileri evre olgulardı. Hastaların \%18.4'ünde beyin metastazı varken, \%81.6'sında ise beyin metastazı yoktu. Koagulasyon testlerinden APTT, PT, INR, \%PT ve fibrinojen değerlerinin beyin metastazı durumu ve sağkalım üzerine istatistiksel anlamlı etkisi saptanmadı ( $>0.05)$. Ancak beyin metastazı olanlarda, olmayanlarla karşılaştırıldığında INR ve \%PT değerlerinde istatiksel olarak anlamlılığa yakın oranda artış tespit edildi (sırasıyla $\mathrm{p}=0.068, \mathrm{p}=0.059$ ).

TARTIŞMA ve SONUÇ: Akciğer kanseri olgularında koagulasyon testlerindeki uzama ile kan beyin bariyerinin de bozulduğu hipotezi ile ilişkili olarak beyin metastazı sıklığında artış oluşabilir ancak daha fazla hasta sayısının olduğu geniş kapsamlı çalışmalara ihtiyaç vardır.

Anahtar Kelimeler: Akciğer kanseri, koagulasyon testleri, kan beyin bariyeri, metastaz

\begin{abstract}
INTRODUCTION: In this study, the effects of changes in coagulation tests on survival and distant organ metastasis in lung cancer patients were investigated.

METHODS: We retrospectively evaluated the data of patients who were diagnosed with primary lung cancer by our radiation oncology clinic. The relationship between age, sex, histopathological diagnosis, metastasis status and coagulation test values and lifespan were analyzed.

RESULTS: A total of 342 patients were included in the study. 18,4\% of the patients had small cell lung cancer (SCLC), and 81,6\% had non-small cell lung cancer (NSCLC). Adenocarcinoma (45.0\%) was the most common histopathological subtype in patients with NSCLC. When distant organ metastasis rates were handled for all patients, while there weren't distant organ metastasis in $44.4 \%$ of patients, distant organ metastasis was found out in 55.6\% of the patients. $65.1 \%$ of patients with SCLC and 53.4\% of patients with SCLC were in advanced stages with distant organ metastasis. $18.4 \%$ of the patients had brain metastasis, and $81.6 \%$ had no brain metastasis. There was no statistically significant effect of APTT, PT, INR, \% PT which are among the coagulation tests, and fibrinogen values on brain metastasis status and survival ( $p>0.05$ ). However, in patients with brain metastases, increase in the ratio close to statistical significance the INR and\% PT values was found $(p=0.068, p=0.059$, respectively) when compared to the non-men.
\end{abstract}


DISCUSSION AND CONCLUSION: In the case of lung cancer, an increase in the frequency of brain metastasis may be associated with the hypothesis that prolongation of the coagulation test and deterioration of the blood-brain barrier, but there is a need for extensive studies with more patients.

Keywords: Lung cancer, coagulation tests, APTT, PT, INR, \% PT, blood-brain barrier, metastasis.

\section{GíRIŞ}

Kanser, dünya genelinde giderek artan bir sağlık problemidir. Bu durum toplumlar için önemli bir sosyoekonomik yüke, bireylerde maddi ve manevi kayip ve zorluklara yol açmaktadır. Dünya kanser istatistiklerine göre; akciğer kanseri, tüm dünyada kanser ölümleri arasında birinci sırada yer almaktadır (1). Hastalıkla mücadelede erken tanı ve tedavi büyük önem taşımaktadır. Ancak akciğer kanseri için önerilen düşük doz bilgisayarlı tomografi tarama yaklaşımı ile erken evrede tümörleri saptamak, invaziv olmayan bir yöntem olarak sunulmasina rağmen avantajlarına ilişkin çelişkili sonuçlar bulunmaktadır $(2,3)$. En gelişmiş tedavi yöntemlerine rağmen, akciğer kanserlerinde erken evre olsa bile beş yıllık sağkalım yaklaşık olarak \%60-70'lerde seyretmekte, ileri evre olgularda ise bu oran $\% 5$ 'in altına düşmektedir. Tüm alt tipler ve evreler göz önüne alındığında, tedavi ile beş y1llı sağkalım oran $1 \% 14$ 'civarındadır. Beyin metastazları ise daha büyük terapötik bir sorun oluşturmaktadır. Çalışmamızda akciğer kanserli olgularda, koagulasyon testlerindeki (aktive partial thromboplastin time: APTT, prothrombin time: PT, international normalized ratio: INR, \%PT ve fibrinojen) bozulma ve uzak organ metastaz1 ilişkisini özelikle beyin metastazı açısından araştırmaya çalıştık. Permeabilite ve vaskülaritenin artması ile sonuçlanan koagulasyon testlerindeki bozulma ile tümör hücrelerinin kan beyin bariyeri ile etkileşim mekanizmaları da bozulmaktadır ve böylece beyin metastazı oranlarında artış görülebilir. Koagulasyon testlerinin beyin metastazı için risk grubu hastaları öngörmede faydalı basit yeni minimal invaziv bir yöntem olarak geliştirilebileceğini düşünmekteyiz.

\section{GEREÇ ve YÖNTEM}

Çalışmamıza Eylül 2013- Eylül 2017 tarihleri arasinda hastanemiz radyasyon onkolojisi kliniğine başvuran ve primer akciğer kanseri tanısı almış 342 hastanın verileri retrospektif olarak bilgisayar kayıtları ve hasta dosyaları üzerinden incelendi. Yaș, cinsiyet, histopatolojik tan1, tek veya multipl metastaz durumu ve metastaz yerleri kaydedildi. Tanı öncesi koagulasyon testleri olan APTT, PT, INR, \%PT ve fibrinojen testlerindeki bozuklukların beyin metastazı ve diğer uzak organ metastazı üzerine etkisi olup olmadığ araştırıldi.

\section{İstatistiksel değerlendirme}

Araştırmadan elde edilen veriler kodlandıktan sonra SPSS (Version 22 for Windows, SPSS Inc, Chicago, IL, USA) paket programinda bilgisayara aktarılmış ve analiz edilmiştir. Veriler değerlendirilirken sürekli değişkenler parametrik ise ortalama \pm standart sapma ile parametrik değilse ortanca (minimum ve maksimum değer) ile ifade edilirken, frekans veriler ise sayı ve yüzde (\%) ile belirtilmiştir. İstatistiksel analizlerde tüm ölçümsel değişkenlerin normal dağılıma uygunluğu "Kolmogorov-Smirnov Testi" ile değerlendirilmiştir. Frekans verilerin gruplar arası karşılaştırmasında "Pearson Ki-kare Testi" ve "Fisher'in Kesin Testi" kullanılmıştır. Sürekli değişkenlerin gruplar arası karşılaştırması, normal dağılıma uymayan değişkenler olduğu için "Mann-Whitney U Testi" kullanılarak yapılmıştır. Bu analizlerden belirlenen olası faktörler dikkate alınarak sağ kalıma etki edebilecek bağımsız etkenler, geriye doğru (backward) seçim yöntemi ile Cox regresyon analizi ile değerlendirilmiştir. İstatistiksel anlamlılık düzeyi tüm testler için $\mathrm{p}<0.05$ olarak kabul edilmiştir.

\section{BULGULAR}

Değerlendirmeye alınan toplam 342 olgunun yaş ortalaması $63.7 \pm 10.3$ (ortanca: 64), yaş aralığ 28-89 idi. Olguların \%6.1'i (21 hasta) kadın, \%93.9'ü (321 hasta) erkek hastalardan oluşmaktaydı. Olguların \%18.4'ü (63 hasta) KHAK iken, \%81.6's1 (279 hasta) KHDAK tanısına sahipti. KHAK grubundaki hastaların \%6.3'ü kadın ve \%93.7'si erkekti. KHDAK grubundaki hastaların ise \%6.1'i kadın, \%93.9'si erkekti (Tablo 1).

Patolojik alt tipler açısından değerlendirme yapıldığında KHDAK'li hastaların $\% 45^{\prime} \mathrm{i}$ 
adenokarsinom, \%32.2'si skuamöz hücreli karsinom (SCC), \%2.6's1 nöroendokrin karsinom ve \%1.8 diğer (malign mezenkimal tümör, dev hücreli tümör karsinoid, bazoloid karsinom) kanserlerden oluşmaktaydı. En sık görülen histopatolojik alt tipin adenokarsinom olduğu belirlendi. Adenokarsinomların $\% 91.6$ 's1, SCC tanısına sahip olanların \%97.3'ü ve toplam 9 nöroendokrin kanser tanılı hasta erkekti (Tablo 1).
Tüm hastaların metastaz oranlarına bakıldığında, hastaların \%55.6'sında (190 hasta) uzak organ metastazı varken, \%44.4'ünde (152 hasta) herhangi bir uzak organ metastazı yoktu. KHAK'li olguların $\% 65.1$ 'inde ve KHDAK'li olguların $\% 53.4$ 'ünde uzak organ metastazı mevcuttu (Tablo 2).

Tablo 1: Hasaların cinsiyet ve patolojik tipe göre dağılımı

\begin{tabular}{|c|c|c|c|c|c|c|c|}
\hline & & $\begin{array}{l}\text { Adenokarsino } \\
\text { m }\end{array}$ & SCC & KHAK & Nöroendokrin ca & Diğer & Total \\
\hline \multirow[t]{3}{*}{ Erkek } & Hasta sayısı & 141 & 107 & 59 & 9 & 5 & 321 \\
\hline & Cinsiyet (\%) & 43.9 & 33.3 & 18.4 & 2.8 & 1.6 & 100.0 \\
\hline & $\begin{array}{l}\text { Patolojik tip } \\
(\%)\end{array}$ & 91.6 & 97.3 & 93.7 & 100.0 & 83.3 & 93.9 \\
\hline \multirow{3}{*}{ Kadın } & Hasta sayısı & 13 & 3 & 4 & 0 & 1 & 21 \\
\hline & Cinsiyet (\%) & 61.9 & 14.3 & 19.0 & 0.0 & 4.8 & 100.0 \\
\hline & $\begin{array}{l}\text { Patolojik tip } \\
(\%)\end{array}$ & 8.4 & 2.7 & 6.3 & 0.0 & 16.7 & 6.1 \\
\hline \multirow{3}{*}{ Total } & Hasta sayısı & 154 & 110 & 63 & 9 & 6 & 342 \\
\hline & Cinsiyet (\%) & 45.0 & 32.2 & 18.4 & 2.6 & 1.8 & 100.0 \\
\hline & $\begin{array}{l}\text { Patolojik tip } \\
(\%)\end{array}$ & 100.0 & 100.0 & 100.0 & 100.0 & 100.0 & 100.0 \\
\hline
\end{tabular}

Tablo 2: Herhangi bir uzak organ metastaz mevcudiyeti

\begin{tabular}{|c|c|c|c|c|}
\hline & & Metastaz var & Metastaz yok & Total \\
\hline \multirow[t]{3}{*}{ KHAK } & Hasta sayısı & 41 & 22 & 63 \\
\hline & Hasta sayısı (\% ) & 65.1 & 34.9 & 100.0 \\
\hline & Toplam (\% ) & 21.6 & 14.5 & 18.4 \\
\hline \multirow[t]{3}{*}{ KHDAK } & Hasta sayısı & 149 & 130 & 279 \\
\hline & Hasta sayısı (\% ) & 53.4 & 46.6 & 100.0 \\
\hline & Toplam (\% ) & 78.4 & 85.5 & 81.6 \\
\hline \multirow[t]{2}{*}{ Total } & Hasta sayısı & 190 & 152 & 342 \\
\hline & Toplam (\% ) & 55.6 & 44.4 & 100.0 \\
\hline
\end{tabular}

KHAK olguların \%34.9'unda herhangi bir metastaz yokken, \%28.6'sinda tek metastaz,
$\% 36.5$ 'sinda ise 2 ve daha fazla sayıda metastaz mevcuttu. Aynı oranlar KHDAK olgularında Adress for correspondence: Sema yılmaz Rakııı, Rize Eğitim Ve Araştırma Hastanesi Radyasyon Onkolojisi Binası 53100 Rize - Türkiye 
sirasiyla \%46.6 (metastaz yok), \%21.9 (tek metastaz) ve \%31.5 (multipl metastaz) olarak belirlenmiştir. Metastaz sayısı açısından KHAK ve KHDAK istatistiksel olarak anlamlı fark yoktu $(\mathrm{p}=0.22)$.

Toplam 342 hasta beyin metastazı açısından değerlendirildiğinde ise olguların \%81.6'sinda (279 hasta) beyin metastazı yokken, \%18.4'ünde (63 hasta) beyin metastazı vardı. KHAK grubundaki hastaların \%73'ünde ( 46 hasta) beyin metastazı yokken, \%27'sinde (17 hasta) beyin metastazı vard1. KHDAK grubunda ise hastaların \%82.6'sinda (187 hasta) beyin metastazı yokken, \%17.4 (46 hasta) beyin metastaz1 vard1.

Hastaların APTT, PT, INR, \%PT ve fibrinojen değerlerine ait istatistiksel değerler tablo 3'de özetlenmiştir. APTT ortalamas1 $32.54 \pm 6.82$ (medyan 31.50), PT ortalamas1 $14.09 \pm 2.68$ (medyan 13.60), INR ortalamas1 $1.13 \pm 0.69$ (medyan 1.05), \%PT ortalamas1 $91.50 \pm 18.35$ (medyan 92.00) ve fibrinojen ortalamas1 525.64 \pm 199.35 (medyan 483.50) bulundu.

Koagülasyon testlerindeki uzama ile herhangi bir uzak organ metastazı olmas1 arasında anlamlı ilişki tespit edilmedi. (APTT, PT, INR, PT \% ve fibrinojen $\mathrm{p}$ değerleri sırası ile $0.453,0.272,0.168,0.203$ ve 0.270 ). Koagülasyon test değerlerindeki uzama ile takip süresi arasındaki ilişkiye bakıldığında KHAK ve KHDAK grupları için karşılaştırıldı ̆̆ında istatistiksel anlamlı fark bulunmadı $(p>0.05$, $\mathrm{p}=0.141$ ).

Beyin metastazı mevcudiyeti ve koagülasyon test değerleri tablo 4'te gösterilmiştir. INR ve \%PT değerleri beyin metastazı olan ve olmayan hastalar için karşılaştırıldığında, aradaki fark istatiksel olarak anlamlılığa yakın bulundu (sirasıyla $\mathrm{p}=0.068$ ve $\mathrm{p}=0.059$ ). APTT, PT ve fibrinojen için aradaki fark istatiksel olarak anlamlı değildi ( sirasiyla $\mathrm{p}=0.849, \mathrm{p}=0.11$ ve $\mathrm{p}=0.633$ ).

Tablo 3: Hastaların koagulasyon test değerleri

\begin{tabular}{|l|l|l|l|l|l|}
\hline & APTT & PT & INR & \%PT & Fibrinojen \\
\hline Hasta sayısı & 279 & 340 & 340 & 339 & 96 \\
\hline Ortalama & 32.54 & 14.09 & 1.13 & 91.50 & 525.64 \\
\hline Ortanca & 31.50 & 13.60 & 1.05 & 92.00 & 483.50 \\
\hline Standart Sapma & 6.82 & 2.68 & 0.69 & 18.35 & 199.35 \\
\hline Minimum & 20.60 & 11.47 & 0.03 & 18.00 & 40.00 \\
\hline Maksimum & 99.80 & 41.10 & 12.70 & 136.00 & 1191.00 \\
\hline
\end{tabular}

Tablo 4: Beyin metastazı mevcudiyeti ve koagülasyon test değerleri

\begin{tabular}{|l|l|l|l|l|l|l|}
\hline & & APTT & PT & INR & PT \% & Fibrinojen \\
\hline $\begin{array}{l}\text { Beyin metastazi yok } \\
\text { N=279 }\end{array}$ & Hasta say1s1 & 223 & 277 & 277 & 276 & 80 \\
\cline { 2 - 7 } & Ortalama & 32.60 & 13.94 & 1.13 & 92.50 & 522.34 \\
\cline { 2 - 7 } & Ortanca & 31.50 & 13.50 & 1.04 & 93.00 & 479.50 \\
\hline & Standart Sapma & 7.13 & 2.29 & 0.74 & 17.29 & 198.47 \\
\hline $\begin{array}{l}\text { Beyin metastazi var } \\
\text { N=63 }\end{array}$ & Hasta say1s1 & 56 & 63 & 63 & 63 & 16 \\
& Ortalama & 32.28 & 14.73 & 1.16 & 87.09 & 542.12 \\
\hline & Ortanca & 31.45 & 13.80 & 1.06 & 90.00 & 506.50 \\
\hline & Sd. Deviation & 5.502 & 3.94 & 0.47 & 22.03 & 209.51 \\
\hline
\end{tabular}


Metastazı olmayan, tek veya multipl metastazlı hastaların APTT, PT, INR, \%PT, fibrinojen değerleri karşılaştırıldığında, üç grup arasında istatiksel fark yoktu $(\mathrm{p}>0.05)$ ( $\mathrm{p}$ değerleri siras1 ile $0.192,0.820,0.489,0.590,0.533$ ve 0.370 ). Bu üç grup arasındaki tek anlamlı fark ise takip süresi idi (p:0.000). Ayrıca bu gruplar arasında ikili karşılaştırmalar mann whitney U testi ile yapıldı. Bu sonuçlarına göre her üç grubun takip sürelerinin istatistiksel olarak anlamlı düzeyde birbirinden farklı olduğu belirlendi (p:0.000).

Beyin metastazı olmayan hastalarda takip süresi ortalama $17.18 \pm 15.80$ (ortanca:13.0) ay iken, beyin metastazı olanlarda $6.46 \pm 6.59$ (ortanca: 6.0) ay bulundu. Takip süresi hiç metastazı olmayanlarda ortalama $21.2 \pm 17.6$ (ortanca:16.0) ay, tek metastazı olanlarda $13.0 \pm 11.3$ ( ortanca 9 ) ay, en kısa takip süresi ise iki veya daha fazla metastazı olanlarda $8.4 \pm 9.5$ (ortanca 5) ay olduğu tespit edildi. Şekil $1^{\text {'de metastaz }}$ mevcudiyetinin sağkalım üzerine etkisini yansıtan sağkalım eğrisi görünmektedir Metastaz mevcudiyeti yaşam süresini istatistiksel olarak anlamlı düzeyde kısaltan en önemli prognostik faktör oldu (p:0.000).

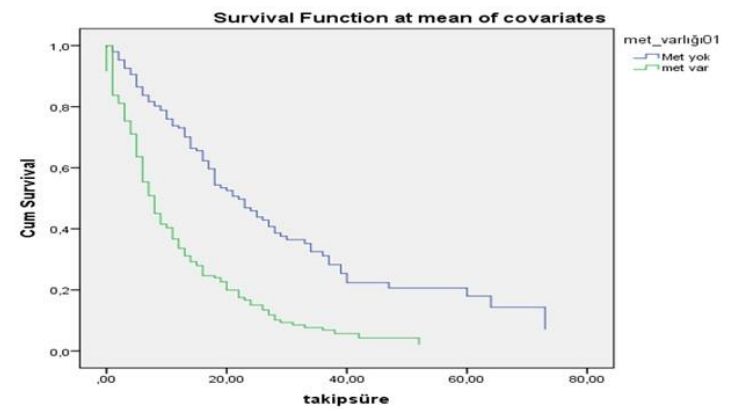

Resim 1: Metastaz mevcudiyetinin sağkalım üzerine etkisini gösteren sağkalım eğrisi.

Herhangi bir uzak metastazı olmayan hastaların yaş ortalaması $64.7 \pm 9.2$ (ortanca: 65.0 ) y1l idi. Tek metastazı olan 79 hastanın yaş ortalaması $63.8 \pm 9.3$ (ortanca:64.0) y1l iken, iki ve daha fazla met olan 111 olgunun yaş ortalaması $62.0 \pm 10.9$ (ortanca:64.0 ) y1l olduğu belirlendi. Metastaz mevcudiyeti ve sayısı genç hastalarda daha fazla olsada, yaş açısından üç grup arasinda istatistiksel fark saptanmad $1(\mathrm{p}=0.192)$. Beyin metastazı olanlarda yaş ortalaması $61.4 \pm 11.3$ iken, beyin metastazı olmayanlarda $64.1 \pm 9.4$ idi. Aradaki fark istatiksel olarak anlamlı olmasa da (p:0.134) beyin metastazı olanların da olmayanlara göre nispeten daha genç hastalar olduğu tespit edildi.

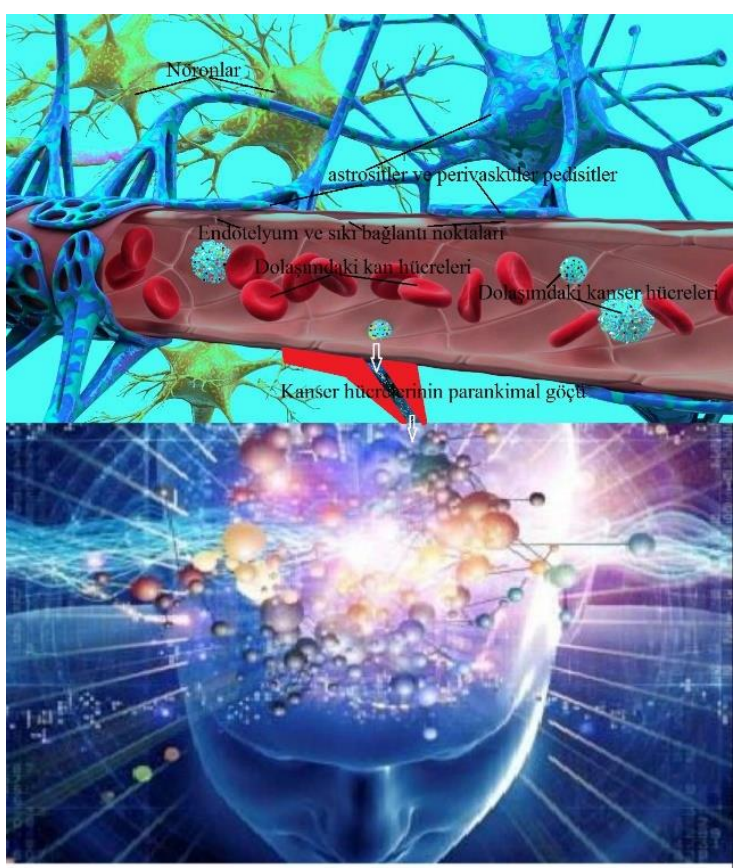

Resim 2. a: Kan beyin bariyerinin k1lcal endotel hücreleri ve sıkı bağlantı noktaları, astrositler ve astrositlerin perivasküler ayakları. b: Bariyeri aşan kanser hücresinin parankimal göç ederek beyin metastazı yapması

\section{TARTIŞMA}

Akciğer kanseri görülme insidansı yaşla artmakta ve 6.-7. dekadlarda pik yapmaktadır. Çalışmamızdaki hastalar büyük oranda 6.dekat hastalarından oluşmaktadır. Beyin metastazı olanlarda yaş ortalaması olmayanlara göre 3 yaş daha genç olmakla beraber aradaki fark istatiksel olarak anlamlı değildi. Dünya genelinde akciğer kanseri insidansina bakıldığında erkek/kadın $5 / 1$ oranında seyrederken ülkemizde erkek/kadın oranı 9/1 civarındadır (4). Ülkemizdeki oranlar erkekler için dünya insidansının üzerinde seyrederken, kadınlarda dünya istatistiklerinin altındadır. Toraks Derneği Akciğer ve Plevra Maligniteleri Çalışma Grubu tarafından yapılan ulusal, hastane bazlı retrospektif çalışmada, 11849 akciğer kanserli olgunun \% 90.4'ünün erkek, \% 9.6'sının kadın olduğunu belirlemiştir (5). Bizim çalışmamızda ise erkek/kadın oran 15/1 şeklinde olup, bu oran ülke ve dünya genelinden çok daha düşüktür. Bu durum kadınların sağlık hizmetlerine ulaşımındaki yetersizliğinden ve

Adress for correspondence: Sema yılmaz Rakıcı, Rize Eğitim Ve Araștırma Hastanesi Radyasyon Onkolojisi Binası 53100 Rize - Türkiye

e-mail: sema.rakici@erdogan.edu.tr

Available at www.actaoncologicaturcica.com

Copyright $\odot$ Ankara Onkoloji Hastanesi 
sigara içme oranının erkeklerden çok daha az olmasından kaynaklanabilir.

Çalışmamızda hastalarımızın \%45'inde adenokarsinom, \%32.2'sinde SCC ve \%18.4'ünde KHAK mevcuttu. Türkiye birleşik veri tabanı 2014 verilerine göre ülkemizde en s1k görülen histopatolojik alt tip adenokarsinom $\% 43.8$ iken, bunu \%37.5 oran1 ile SCC ve \%16.6 ile KHAK izlemektedir (6). Türkiye'de olduğu gibi $A B D$ ve Japonya'da da en sik adenokarsinom saptanırken Asya ülkelerinde SCC halen en s1k görülen kanser tipidir (7-9).

Akciğer kanserli olgular büyük oranda metastatik (evre IV) ya da lokal ileri evrede (evre IIIA ve IIIB) saptanmaktadır. Bundan dolayı olguların \%70'i tanı anında küratif tedavi şansına sahip olamamaktadır (7). 1994-1998 yılları arasında Türkiye'de akciğer kanseri paternini belirlemek için yapılmış retrospektif çalışma verilerine göre, ülkemizde akciğer kanserli olguların \%86.7'si evre III ve IV'de yer almakta ve bunların da \%40.4'ü evre IV hastalardan oluşmaktadır (5). 2017 yılına ait Sağlık Bakanlığı kanser dairesi başkanlığı istatistiği verilerine göre evre IV hasta oranının \%52.7 olduğu bildirilmektedir (6). Bugün, geçmişe göre evre IV hasta oranının artmış olarak görünmesi kanser istatistiklerinin daha iyi tutuluyor olmasından ve tanıyı koyduracak ileri teşhis metotlarının geliştirilmiş olmasından kaynaklanabilir. Bizim çalışmamızda tüm gruplar için tanı anındaki uzak organ metastaz oranını \%55.6 bulduk. Bu oranlar KHAK'de \%65.1 iken KHDAK'de \%53.4 idi. KHAK sıklığı daha düşük olsada, bu hastalar tanı anında çoğunlukla metastatik evrede karşımıza çıkmaktadır. Multipl metastaz durumuna baktığımızda, KHAK'de \%36.5 iken KHDAK'de \%31.5 olarak tespit edildi. Çalışmadaki tüm hastalar sadece beyin metastazı açısından değerlendirildiğinde, hastaların \%18.4'ünde beyin metastazı vardı. $\mathrm{Bu}$ oranlar KHAK'de \%27 iken, KHDAK'de $\% 17.4$ idi. KHAK tüm akciğer kanseri vakalarının \%20'sini oluşturmasına karşın, yaklaşı $\% 50$ sinde beyin metastazı bulunduğu belirtilmektedir (10). Bunun sebebi akciğer kanserlerinin diğer kanserlere göre daha fazla beyin metastazı yapma eğiliminde olması, tümörün sistemik dolaşımla direkt teması ve yüksek biyolojik agresivitesi ile açıklanmaktadır $(11,12)$. Çalışmamızda beyin metastazı ile diğer uzak organ metastazı oranlarına baktığımızda, beyin metastaz oranının daha az s1klık gösterdiğini tespit ettik. $\mathrm{Bu}$ durumun kan beyin bariyerinin koruyucu etkisinden kaynaklanabileceğini düşünmekteyiz. Çünkü beyin kapiller duvarlarının sıkı endotelyal hücre tabakası, sık1 bağlantı noktaları ve astrositlerin ayak yapısı nedeniyle kanser hücreleri tarafindan beyin parankiminin penetre edilmesi oldukça zordur ( 13-15).

Uzak organ metastaz oluşumu, kanser hücrelerinin kan veya lenfatik yoluyla taşınması sonrası oluşmaktadır. Santral sinir sisteminde lenfatik sistem bulunmadığından, kanser hücrelerinin beyne ulaşması için tek olasılık kan dolaşımıdır. Tümör hücrelerinin metastatik progresyonu "metastaz kaskadi" olarak adlandırılan bir süreç ile oluşmaktadır. Bu adımlar lokal invazyon, intravazasyon (kan dolaşımına içine geçiş), kanser hücrelerinin dolaşımda hayatta kalması, ekstravazasyon (spesifik hedef organa ilerlemek) ve kolonizasyon (yerleştiği mikroçevrede büyümenin başlaması) şeklinde sayılmaktadır ( 15-19). Metastazın önündeki engeller organlara göre farklıklar göstermektedir. Beyin parankiminine kolonize olmak için tümör hücrelerinin öncelikle kan beyin bariyerine nüfuz etmeleri gereklidir ( 19). Daha sonra bu metastatik hücreler, kan beyin bariyeri kapiller endotel hücresi tabakasından geçerek beyin parankimine ulaşması gerekmektedir $(20,21)$. Organizmada en s1k görülen endotel bariyerini temsil eden kan beyin bariyeri, yalnızca çözünen maddelerin değil, aynı zamanda, beyin parankimi ile kapiller endotel arasındaki hücre trafiğine de engel oluşturmaktadır. $\mathrm{Bu}$ bariyerden geçişte, kanser hücrelerinin hareketliliği ve göçüyle ilgili etkileyici miktarda veriye rağmen, kanser hücreleri ve serebral endotel bariyer arasındaki etkileşim mekanizmaları tam olarak karakterize edilememiştir. $\mathrm{Bu}$ durumu açıklayıcı mekanizmalar arasında, junctional ve adezyon moleküllerinin rolü, çözünebilir faktörler, proteolitik enzimler, tümör hücrelerinin beyin endotel hücrelerine bağlanmasına aracılık eden sinyal yolakları ve metastatik hücrelerin transendotelyal göçü sayılabilir (20). Bu basamaklarda bağışıklık sisteminin ve metastatik hücrelerin farklı fizyolojik, moleküler ve mekanik 
özelliklerinden dolayı bazı farklılıklar bulunmaktadir (22).

Çalışmamızda beyin metastazı olanlarda, olmayanlara göre INR ve \%PT test değerlerinde bozulma oranını istatiksel anlamlılığa yakın oranda ilişkili olduğunu tespit ettik. Beyin dışı uzak organ metastaz ile koagulasyon testleri arasında ise anlamlı ilişki tespit edilmedi. Koagulasyon testlerindeki bozulma sonucunda zayıf da olsa beyin metastazı ilişkisinin tespit edilmesi, metastatik hücrelerin geçişinde koruyucu rol üstlenen kan beyin bariyerinin yapısının bozulmasından kaynaklanabilir. $\mathrm{Bu}$ durum kapiller permeabilite ve vaskülaritenin artmasın sonucunda tümör hücrelerinin kan beyin bariyeri ile etkileşim mekanizmalarını bozulması sonucunda beyin metastazı oranlarının arttığını düşünmekteyiz. Arshad ve ark. (15) çalışmasında beynin vaskülar yapılarının geçirgenliği ve bütünlügündeki değişiklikleri bloke edilerek, metastaz anjiyogenezini ve tümör büyümesini inhibe edebilecek terapötik yaklaşımların tasarlanabileceği belirtmektedir. $\mathrm{Bu}$ çalışma kan beyin bariyerinin yapısındaki değişikliklerin metastaz etiyolojisinde rolü olabileceğine işaret etmektedir. Herhangi bir nedenle gelişen beyin ödeminde dahi kan beyin bariyeri bozulduğu bilinmektedir (23).

Koagulasyon testlerinin bozulmasinın sonucunda da vasküler geçirgenliğin atması ile beyin ödemi oluştuğu bilinmekte ve bunun da kan beyin bariyerinin bozuması ile sonuçlanması muhtemeldir. İnflamasyon, oksijen türevi serbest radikaller, platelet aktive eden faktör, histamin, bradikinin, serotonin, sitokinler, iskemi reperfüzyon, radyasyon, akut hipertansiyon, ensefalomiyelitler, beyin tümörleri, hiperkapni, hipoksi, konvulsiyonlar, akut hipertansiyon gibi çok çeşitli nedenlerle kan beyin bariyerini bozarak permeabilite artışına neden olmaktadır (24-29). Kan beyin bariyeri bozulduktan sonra metastatik kanser hücrelerinin beyin parankimine geçişi kolaylaşmaktadır. Endotelyal bariyeri geçmek, yaygin olarak metastatik progresyon sirasinda, tümör yayılımı için en önemli adım olarak kabul edilmektedir (30). Tümör hücreleri transendoteliyal geçiş yapmak için paraselüler ve transselüler olmak üzere iki yol kullanmaktadır (30,31). Paraselüler geçiş, tümör hücrelerinin komşu endotelyal hücreler arasındaki endotelyal hücre bağlantılarının bozulması sonrası gerçekleşen geçiştir. Yukarıda belirttiğimiz faktörlerin yanı sıra kanser hücreleri de çeşitli faktörler salgilayarak endotel hücre birleşimindeki sık1 bağlantı noktalarını açarak bu yolla geçişi sağlayabilirler (31). Transselüler geçişte ise tümör hücrelerinin doğrudan endotelyal hücre gövdesi içinden göçünü ifade eder. Bu geçiş yolu, tümör hücreler tarafından paraselüler göç mekanizmasından daha az siklıkla kullanılmaktadır (32). Muhtemelen kaogülasyon testlerindeki bozulmanın neden olduğu vasküler permeabilite artışı ile kan beyin bariyerinin bozulması sonucundaki beyin metastazları bu yolla gerçekleşmektedir.

Kan beyin bariyeri; kandan, merkezi sinir sisteminin dokularına giden maddelerin geçişlerine karşı sıkı kontrol sağlayan koruyucu bir yapıdır. Bariyerin ana yapısal bileșeni endotelyal hücrelerin s1k1 bağlantılarla kapatılan ve böylece sürekli tipte kılcal kısımlar tarafindan oluşturulmuş kılcal endotelyumdur ve kılcal damarların taban zarı, astrositlerin perivasküler ayakları ile çevrelenmiştir. Kan beyin bariyeri ve bariyerin aşılması ile sonuçlanan beyin metastazı oluşumu şekil 2'de gösterilmiştir. $\mathrm{Bu}$ bariyer, nöronal mikroçevrenin spesifik doğasını sağlamak için önemli fonksiyonları yerine getirmektedir (20,33). Kan beyin bariyeri, k1lcal damarların endoteli boyunca maddelerin hareketleri üzerinde vücudun diğer dokularından daha sıkı kontrol sağlayarak, dolaşımındaki maddelerin merkezi sinir sistemini dokularına geçişini kisitlar (34). Böylece metastatik kanser hücrelerinin de dahil olduğu çoğu maddenin beyne geçişi engellenir. Bu bir bakıma beynin kanserden korunduğu anlamına da gelmektedir. Ancak çeşitli nedenlerle bu yapının bozulduğu durumlarda kan beyin bariyeri aşılarak beyin parankimine tümör geçişi oluşabilmektedir.

\section{SONUÇ}

Sonuç olarak, kan beyin bariyeri bozukluğu dinamik bir süreçtir ve beyin metastazı oluşumunda önemli bir adımı temsil eder. Metastatik tümör hücrelerin endotel hücreleri ile teması ve parankimal göçü çeşitli nedenlerin etkileşimine bağlıdır. Karmaşık yapıs1 ve mekanizması nedeniyle kan beyin bariyeri fonksiyonlarını tam olarak anlamak 
için daha ileri incelemeler gerekmektedir. Koagülasyon testlerindeki bozukluklar kan beyin bariyerinin endotelyal permeabilite ve vaskülaritenin artması ile sonuçlanmaktadır. Bunun sonucunda kanser hücrelerinin beyin parankimine geçişleri daha kolay gerçekleşebilir. Akciğer kanseri olgularında koagulasyon testlerindeki bozuklukla ile ilişkili olarak beyin metastazı sıklığında artış oluşabileceğini düşünmekteyiz. Çalışmamızda \%PT ve INR değerleri ile beyin metastazı oranlarında istatiksel olarak anlamlılığa yakın ilişki tespit edildi. $\mathrm{Bu}$ durum incelediğimiz kadarıyla literatürde daha önce hiç bildirilmemiştir. $\mathrm{Bu}$ sebeple daha güçlü verilerle ispatı için geniş kapsamlı çalışmalara ihtiyaç vardır.

\section{Çıkar çatışması: Yok}

\section{REFERANSLAR}

1. Gültekin M, Boztaş G. Türkiye kanser istatistikleri. Sağlık Bakanlığı, Türkiye Halk Sağlığı Kurumu. 2014; 43.

2. Henschke CI, Yankelevitz DF, Libby DM, Pasmantier MW, Smith JP, Miettinen OS. International Early Lung Cancer Action Program Investigators. Survival of patients with stage I lung cancer detected on CT screening. N Engl J Med. 2006; 355: 1763-71.

3. Bach PB, Jett JR, Pastorino U, Tockman MS, Swensen SJ, Begg CB. Computed tomography screening and lung cancer outcomes. JAMA. 2007; 297: 953-61.

4. Köktürk N, Yeğin D, Çiftçi UT, Mullaoğlu BS, Öztürk C. Akciğer kanserlerinde epidemiyolojik özellikler yıllar içinde değişim gösteriyor mu? Toraks Dergisi. 2004; 5: 137-42.

5. Lung and Pleural Malignancies Study Group. Pattern of lung cancer in Turkey 1994-1998. Turkish Thoracic Society. Respiration. 2002; 69: 207-10.

6. TC sağlık bakanlığı Türkiye halk sağlığı kurumu kanser istatistikleri. Ankara 2017. http://kanser.gov.tr/daire-faaliyetleri/kanseristatistikleri.

7. Spiro SG, Porter JC. Lung cancer-Where are we today? Current advances in staging and nonsurgical treatment. Am J Respir Crit Care Med. 2002; 166: 1166-96.

8. Skuladottir H, Olsen JH, Hirsch FR. Incidence of lung cancer in Denmark: historical and actual status. Lung Cancer. 2000; 27: 107-18.

9. Cha $\mathrm{Q}$, Chen $\mathrm{Y}, \mathrm{Du} \mathrm{Y}$. The trends in histological types of lung cancer during 1980-1988, Guangzhou, China. Lung Cancer. 1997; 17: 219-30.

10. Meert AP, Paesmans M, Berghmans T, Martin B, Mascaux C, Vallot F, et al. Prophylactic cranial irradiation in small cell lung cancer: A systematic review of the literature with meta-analysis. BMC Cancer. 2001; 1: 5 .

11. Altman E, Cadman E. Analysis of 1539 patients with cancer of unknown primary site. Cancer. 1986; 57 : $120-4$.

12. Kömürcüoğlu $A$, Kömürcüoğlu $B$, Konya $A$, Ediboğlu H, Utkaner G, Çelikten E, ve ark. Beyin metastazı semptomları ile ortaya çıkan akciğer kanserleri. Solunum Hastalıkları. 2003; 14: 41-5.

13. Weil RJ, Palmieri DC, Bronder JL, Stark AM, Steeg PS. Breast cancer metastasis to the central nervous system. Am J Pathol. 2005; 167: 913-20.

14. El Kamar FG, Posner JB. Brain metastases. Semin Neurol. 2004; 24: 347-62.

15. Arshad F, Lili Wang L, Sy C, Avraham S, Avraham HK. Blood-Brain Barrier Integrity and Breast Cancer Metastasis to the Brain. Patholog Res Int. 2011; 2011:1-12.

16. Labelle M, Hynes RO. The initial hours of metastasis the importance of cooperative host-tumor cell interactions during hematogenous dissemination. Cancer Discov. 2012; 2: 1091-9.

17. van Zijl F, Krupitza G, Mikulits W. Initial steps of metastasis cell invasion and endothelial transmigration. Mutat Res. 2011; 728: 23-34.

18. Nguyen DX, Bos PD, Massague J. Metastasis from dissemination to organ-specific colonization. Nat Rev Cancer. 2009; 9: 274-84.

19. Bos PD, Nguyen DX, Massague J. Modeling metastasis in the mouse. Curr Opin Pharmaco. 2010; 10: 571-77.

20. Wilhelm I, Molnar J, Fazakas C, Hasko J, Krizbai IA. Role of the blood-brain barrier in the formation of brain metastases. Int J Mol Med Sci. 2013; 14: 1383411.

21. Jia $\mathrm{W}, \mathrm{Lu} \mathrm{R}$, Martin TA, Jiang WG. The role of claudin-5 in blood-brain barrier (BBB) and brain metastases. Mol Med Rep. 2014; 9: 779-85.

22. Strell C, Entschladen F. Extravasation of leukocytes in comparison to tumor cells. Cell Commun Signal. 2008; 6: 10.

23. Germano AF, Tomasello F. Blood-brain barrier permeability changes after subarachnoid haemorrhage: an update. Clinical implications, experimental findings, challenges and future directions. New York: Springer-Verlag Wien; 2001: 5-18.

24. Fenstermacher JD, Rapaport ST. Blood brain barrier. In Handbook of Physiology - The Cardiovascular System. 4 th ed. New York: American Physiological Society. 1984: 969-1000.

25. Stanness KA, Westrum LE, Fornaciari E, Mascagni P, Nelson JA, Stenglein SG, et al. Morphological and functional characterization of an In vitro blood-brain barrier model. Brain Res. 1997; 771:329-342.

26. Gültürk S, İmir G, Tuncer E. Kan beyin bariyeri. Erciyes Medical Journal. 2007; 29: 147-154.

27. Abbott NJ, Mendonca LL, Dolman DE. The bloodbrain barrier in systemic lupus erythematosus. Lupus. 2003; 12: 908- 915.

28. Kaya M, Gulturk S, Elmas I, Kalayci R, Arican N, Kocyildiz ZC, et al. The effects of magnesium sulfate on blood-brain barrier disruption caused by intracarotid injection of hyperosmolar mannitol in rats. Life Sci. 2004; 76: 201-12. 
29. Mark KS, Davis TP. Cerebral microvascular changes in permeability and tight junctions induced by hypoxiareoxygenation. Am J Physiol Heart Circ Physiol. 2002; 282: 1485-94.

30. Khuon S, Liang L, Dettman RW, Sporn PH, Wysolmerski RB, Chew TL. Myosin light chain kinase mediates transcellular intravasation of breast cancer cells through the underlying endothelial cells a three-dimensional FRET study. J Cell Sci. 2010; 123: 431-8.

31. Reymond N, d'Agua BB, Ridley AJ. Crossing the endothelial barrier during metastasis. Nat Rev Cancer. 2013; 13: 858-8.
32. Leong H.S, Robertson AE, Stoletov K, Leith SJ, Chin $\mathrm{CA}$, Chien, $\mathrm{AE}$, et al. Invadopodia are required for cancer cell extravasation and are a therapeutic target for metastasis. Cell Rep. 2014; 8: 1558-8.

33. Wolburg H, Lippoldt A.Tight junctions of the bloodbrain barrier: development, composition and regulation. Vascul Pharmacol. 2002; 38: 323-37.

34. Abbott NJ, Ronnback L, Hansson E.Astrocyteendothelial interactions at the blood-brain barrier Nature Rev Neurosci. 2006; 7: 41-53. 